\title{
Discussion on the Current Situation and Development of Countermeasures for Badminton Teaching in Colleges and Universities
}

\author{
Jun Tao \\ Physical Education Department \\ Wuhan Technology and Business University \\ Wuhan, China
}

\begin{abstract}
Badminton is a systemic sport, which is entertaining, flexible and national. Badminton is popular with sports fans because of less requirements for court equipment, easily adjustable sports load and participation of minor people. It is certainly difficult for badminton to be promoted in university sports because in university sports promotion, its importance is not high, and it is due to the limitation of site and coaches specialization, which has affected the development of badminton in colleges and universities. In view of the current situation of badminton teaching in colleges and universities, a series of development measures are proposed to meet the needs of college sports.
\end{abstract}

Keywords-common universities; badminton; current situation; strategies

\section{INTRODUCTION}

Badminton sport, as a high and attractive sport, has a farreaching influence and a strong reputation in the world. It requires exquisite movement and changeable technical skills, and therefore, it is certainly difficult to achieve a certain technical level. Badminton has a profound mass base in colleges and universities, and in 1996, badminton club in Chinese college students sports association was established in China University of Geo-sciences (Wuhan), which is the leading badminton activity organization in colleges and universities of our country. Since the founding of the badminton club, its members have been from a few to more than 40 colleges and universities up to now, and it has successfully hosted the 15 th session of the national championship of college students. It has provided a good platform for the college students badminton technology exchanges and cooperation and promoted the development of badminton in colleges and universities of our country. Therefore, studying the current status of badminton teaching in colleges and universities is of great benefit to the development of badminton and the reform of badminton teaching in colleges and universities.

\section{OBJECTIVE ANALYSIS OF BADMINTON TEACHING IN COLLEGES AND UNIVERSITIES}

\section{A. To Carry out the Guideline for PE Curriculum in Ordinary Colleges and Universities}

With the implementation of the "health first" guiding ideology of physical education curriculum, the national ministry of education reformulates the "teaching guidelines of physical education curriculum in national ordinary colleges and universities", which is the guidance document formulated specifically for colleges and universities by our country education administration. Colleges and universities should be strict with the teaching task under the guide of the Guidelines. However, according to the survey results of badminton teaching data in colleges and universities, badminton has not completed the tasks required by the outline and cannot guarantee the completion of the teaching tasks of the system according to the quality and quantity.

\section{B. To Improve the Physical Quality of College Students}

The purpose of badminton teaching in colleges and universities is not to cultivate students into professional players, but to improve the physical quality of college students. The recent survey of college students' health status shows that the food in the school canteen has been greatly improved, personal skills index and morphological index increased, but the students' physical quality is significantly lower, which should cause the badminton teaching department to fall into thinking.

\section{To Improve the College Students'Academic Ability of Badminton}

Sports discipline ability refers to the students' adaptation and qualifications for sports discipline activities and adjusting students behavior and discipline requirements and fitness index, to realize students' physiological and psychological unity. Therefore, improving the physical quality of students is the fundamental goal of badminton teaching in colleges and universities. Therefore, it can be found that the improvement of college badminton ability can effectively promote the improvement of college students' 
physical quality, and on the contrary, promote the deep development of college students' badminton ability.

\section{CURRENT StATUS OF BADMINTON TEACHING IN COLLEGES AND UNIVERSITIES}

Badminton sport is beneficial to healthy development of body and mind and a lifelong sports movement, characterized by its simplicity and complexity, popularity and interest, competition and individuality, and these are all conforming to the requirements of the college students' physical exercise, in line with the college students' physiological and psychological characteristics. Therefore, it has profound mass base in colleges and universities, supported by the vast number of teachers and students. Badminton sport is praised by people, and especially in the 2008 Beijing Olympic Games badminton players create success in China, which shows once again the badminton charm and causes the boom in colleges and universities. However, at present, while badminton in colleges and universities has made some achievements, there are also a series of problems against the healthy development of badminton. The author found, through the survey, that students' level of badminton in colleges and universities is uneven, badminton venue and equipment is insufficient, badminton teaching is simple and badminton coach teachers is not strong and the related college students are lack of competition, etc.

First, the facilities are backward. Sports facilities are the material guarantee for sports activities and the basic conditions for sports activities. According to the survey done by the author, among the surveyed 6 colleges and universities and 2 undergraduate colleges, including my school, 5 colleges and universities had no gymnasium, let alone a dedicated badminton hall. The current needs of students cannot be well met, the badminton project site facilities are poor, and the site facilities construction and management of small ball project need to be strengthened. And because the badminton teaching site in many colleges and universities is outside, and especially the author's northern region is affected by the weather and the sandy environment, the student's enthusiasm in playing the badminton is seriously influenced. Because of the professional characteristics of the author's school, each semester, students' training cycle also happens to be the best time of a year, when it is warm and not sandy, thus the best period of badminton teaching and exercise is missed, which hinders the smooth implementation of badminton teaching plan. Personally, the author thinks that the construction of stadium facilities is the most important factor affecting badminton and other sports activities.

Second, because of the college students from different regions and schools and their different understanding and mastery levels of badminton skills, badminton teachers, in the teaching process, cannot meet the needs of the students in different levels. At the same time, in the teaching process, the teaching method is monotonous, the practice content is boring, and the single technical action is repeated again and again. Thus students feel boring and lose their interest in learning the badminton. This is also a phenomenon in other sports, which requires the attention of sports colleagues.

Third, sports funds are not in place. According to the author's investigation, China's ordinary colleges and universities are far from meeting the needs of teachers and students in sports equipment and venues. According to the author's investigation, in terms of teachers' clothing fees, most colleges and universities maintain around 500 yuan. In terms of badminton sport, feather balls and rackets are easy to run out. Due to the large consumption of badminton equipment, colleges and universities cannot provide enough teaching materials, which prevents the badminton teaching from implementing effectively. Teachers and students sometimes have to buy these equipment themselves.

Fourth, the curriculum is unscientific and the teaching organization is traditional and unitary. As a result of the limited sports facilities, many colleges and universities are also struggling to choose the content of physical education teaching, which is dominated by traditional athletics, football, basketball and volleyball. Therefore, when colleges and universities formulate the sports teaching syllabus, or choose the standard sports exercises for students, they mainly rely on track and field, and put the track and field events first as the compulsory textbooks. Some colleges and universities still have traditional administrative class teaching, where men and women students have classes together and they are in a very big class. It's very difficult to choose the sports according to students' interests.

Fifth, there are no professional coaches for badminton in universities. Most badminton teaching are done by physical education teachers, who are not professional badminton teachers, only knowing some basic knowledge of badminton and not having the professional badminton abilities and related skills, and are short of relevant teaching experience in the badminton course. Thus, in the process of teaching, they can only apply the simple training means and methods to badminton teaching, which causes the poorer teaching quality and poorer development of badminton.

\section{COUNTERMEASURES FOR THE DEVELOPMENT OF BADMINTON TEACHING IN COLLEGES AND UNIVERSITIES}

\section{A. Construction of Venues and Full Use of Facilities}

First of all, the construction of facilities for colleges and universities should attract enough attention, which is the perfect prerequisites and conditions of the construction of the badminton venue, and the scale of reasonably planning arrangement of badminton stadiums and other sports venues construction.

Second, venues and facilities should be made full use of and the service attitude of the venue staff should be strengthened. Except for the normal teaching time, venues can be open to the public. The opening hours can be extended in order to meet the needs of students. If economic conditions are not very abundant, it is also an effective way to build a barrack pavilion with an empty space. In addition, besides the indoor badminton stadium, you can also consider 
the outdoor space. The outdoor badminton court can be built in the school shelter from the wind.

Third, when setting up the venue fee, the student's financial ability should be taken into account. Statistics show that the fee setting about badminton court use in some universities is not reasonable, and even relatively high. Therefore, the school should adjust the use cost of badminton field appropriately, so that students can afford this economic expense, so as to promote the development of badminton sport on campus.

In a word, the reasonable construction and appropriate use of the badminton venue should give a full play to the utility of the resources available, which can effectively promote the popularity of badminton sports on campus.

\section{B. Training Teachers and Strengthening Professional Training}

First of all, we should cultivate a professional faculty. The training can be organized by the sports bureau and university sports association. Schools can increase the introduction of professional teachers, more exchanges with other schools and more chances of mutual learning; Teachers should work hard to improve their own abilities and learn more and study independently to promote the improvement of teaching effects. Secondly, the method of "output import" is adopted. The school should send teachers to communicate with the outside badminton activity groups, and learn the advanced and excellent training methods of the professional team, so as to promote the improvement of teachers' level. At the same time, excellent coaches should be invited to help train the school badminton teachers to promote and improve the training level of teachers and students.

\section{Improving the Competition System and Creating a Competitive Atmosphere}

In order to develop the badminton competition successfully, the improvement of the competition system is the basis and prerequisite. In addition, a well-regulated competition system can help create a good competition environment and promote the development of campus badminton. Undoubtedly, college has incomparable cultural atmosphere, and various colleges and universities can combine to develop badminton activities, and suggest building the network information platform, to provide students with information communication channels and make the students have correct and comprehensive understanding of badminton sport to promote extensive badminton project in the national colleges and universities. Different badminton competitions can be organized in schools to provide students with a space to show themselves to the outside world. In addition, due to the different levels of universities, the hierarchical form of competition can be adopted, to ensure the fairness of the game.

\section{Rational Use of Modern Teaching Methods}

On the basis of the traditional teaching means and methods, through introducing high-tech modern teaching methods and the playing of wonderful badminton matches, the unique aspect of badminton can be shown to students through modern equipment, to attract more students to participate in the badminton. In the course teaching, students can make use of video recording equipment to record the action errors and correct actions, which can let students know their own image mistakes and correct them in a timely manner. In addition, as high-tech equipment involves the funding of education, the school needs to invest some education funds into it.

\section{CONCLUSION}

At present, China's badminton development in colleges and universities is still at the initial stage, but the future development is bright. Colleges and universities should focus on solving the problem of teaching field and equipment, increase capital investment, strengthen teaching staff, accelerate the reform of teaching to meet the needs of students to learn badminton, in order to adapt to the needs of physical education in colleges and universities and the society. Only in this way can badminton develop better in colleges and universities.

\section{REFERENCES}

[1] Liu Junhui, Zhang Chi. Research on Teaching Status of Badminton Elective Courses in Ordinary Universities [J]. Sports World, 2011 (6).

[2] Shao Jinting. Research on the Current Situation of Badminton Teaching in Normal Universities [J]. Science and Technology Information, 2010 (10).

[3] Wang hai. Research on the Current Situation and Development Countermeasures of Badminton Teaching in Colleges and Universities [J]. Exercise, 2013 (2). 